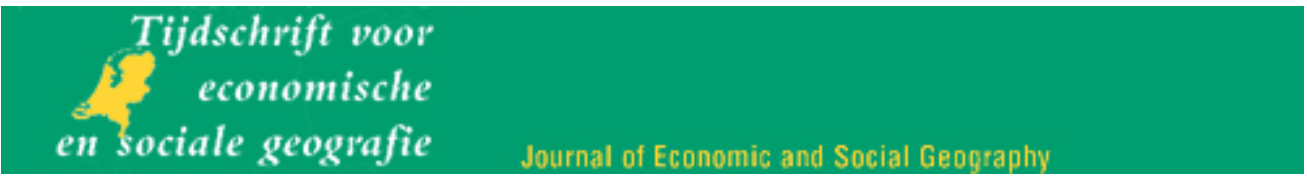

\title{
Detection and simulation of urban expansion and socioeconomic segregation in the Greater Paramaribo Region, Suriname
}

\begin{tabular}{|r|l|}
\hline Journal: & Tijdschrift voor economische en sociale geografie \\
\hline Manuscript ID & TESG-2017-Nov-068.R3 \\
\hline Manuscript Type: & Original Manuscript \\
\hline Keywords: & $\begin{array}{l}\text { urban expansion, residential differentiation, dissimilarity index, } \\
\text { socioeconomic segregation, Google Earth@, Suriname }\end{array}$ \\
\hline \multicolumn{2}{|l}{} \\
\hline
\end{tabular}

\section{SCHOLARONE" \\ Manuscripts}




\section{Detection and simulation of urban expansion and socioeconomic segregation in the Greater Paramaribo Region, Suriname}

This paper analyses built-up area expansion and socioeconomic segregation within the Greater Paramaribo Region, Suriname. Built-up expansion between 1987 and 2015 was assessed via timeseries analysis of Landsat images. By identifying visible spatial residential characteristics in Google Earth ${ }^{\odot}$ images, the residential built-up area was differentiated into Rich, Middle, Middle to low, and Poor residences, signifying different socioeconomic groups.

Results show that the built-up expansion of the region is primarily controlled by the distance to the previously built-up area, city centre, and roads, as well as land price. The observed expansion mainly consisted of Middle and Middle to low residences. Dissimilarity indices demonstrate an increasing socioeconomic segregation, especially between Rich and Poor. A business-as-usual model simulation for 2030 indicates that this segregation is likely to remain.

Keywords: urban expansion; residential differentiation; dissimilarity index; socioeconomic segregation; Google Earth ${ }^{\complement}$; Suriname 


\section{INTRODUCTION}

In 2015, of the world's seven billion people, almost four billion were characterised as urban dwellers (United Nations, 2014a). By 2050, this number is expected to reach six billion (United Nations, 2014b) due to natural population growth, reclassification of areas from rural to urban, and above all rural-to-urban migration (Khan et al., 2014, McGranahan and Satterthwaite, 2014). Such migration is largely opportunistic and related to economic growth, access to basic utilities and services, and a general preference for urban life, creating a rural push and an urban pull dynamic (Tacoli et al., 2015). After Asia and Africa, the third largest urbanised region in 2050 is predicted to be Latin America and the Caribbean (United Nations, 2014b). In countries within this region, often described as developing, industry is underdeveloped. Therefore, the large rural-to-urban migration often cannot be absorbed into urban society, resulting in urbanisation without economic growth or overurbanisation. This is often due to the reliance on natural resource exports, such as oil and gold (Jedwab and Vollrath, 2015, Gollin et al., 2016, Chauvin et al., 2017). Consequently, these countries undergo urbanisation without the financial means to cope with it and its accompanying environmental and social issues. One such an is urban sprawl, which is the uncontrolled, irregular expansion of the urban area (Bhatta, 2010, Ramachandra et al., 2012, Yue et al., 2013, Khan et al., 2014). While urban sprawl can significantly impact biodiversity, soil quality, and local and regional climate, it can also impact the socioeconomic segregation. An overview of the major problems associated with urbanisation is given in Table 1.

Table 1: Overview of some of the major problems associated with urbanisation

\begin{tabular}{|c|c|c|c|c|}
\hline Problem & City & Cause & Consequence & Reference \\
\hline Traffic Congestion & Kampala (Uganda) & $\begin{array}{l}\text { Lack of infrastructure } \\
\text { development, next to } \\
\text { urban sprawl }\end{array}$ & $\begin{array}{l}\text { Long travel times, } \\
\text { reducing access to } \\
\text { urban services and } \\
\text { opportunities }\end{array}$ & $\begin{array}{l}\text { (Vermeiren et } \\
\text { al., 2015) }\end{array}$ \\
\hline \multirow[t]{3}{*}{ Land use conflicts } & $\begin{array}{l}\text { Pearl River Delta } \\
\text { (China) }\end{array}$ & $\begin{array}{l}\text { Ineffective land use } \\
\text { planning }\end{array}$ & $\begin{array}{l}\text { Loss of (potential) } \\
\text { agricultural land }\end{array}$ & (Du et al., 2014) \\
\hline & India & $\begin{array}{l}\text { Urbanisation due to } \\
\text { industrialisation and } \\
\text { migration }\end{array}$ & Agricultural land loss & $\begin{array}{ll}\text { (Pandey and } \\
\text { Seto, 2015) }\end{array}$ \\
\hline & Mumbai (India) & $\begin{array}{l}\text { Urbanisation due to } \\
\text { population growth and } \\
\text { sewage treatment }\end{array}$ & $\begin{array}{l}\text { Loss of mangrove } \\
\text { forest ecosystem }\end{array}$ & $(\mathrm{Vaz}, 2014)$ \\
\hline \multirow[t]{2}{*}{ Social segregation } & Beijing (China) & $\begin{array}{l}\text { Unequal and } \\
\text { uncontrolled urban } \\
\text { sprawl }\end{array}$ & $\begin{array}{l}\text { Lack of urban public } \\
\text { services and } \\
\text { transportation } \\
\text { services in poor } \\
\text { neighbourhoods }\end{array}$ & (Zhao, 2013) \\
\hline & $\begin{array}{l}\text { Greater } \\
\text { Metropolitan } \\
\text { Area of Costa Rica }\end{array}$ & Sprawling city limits & $\begin{array}{l}\text { Overcrowded, poor } \\
\text { informal settlements }\end{array}$ & $\begin{array}{l}\text { (van Lidth de } \\
\text { Jeude et al., } \\
2016)\end{array}$ \\
\hline Urban hazards & & & & \\
\hline
\end{tabular}


$\begin{array}{lll}\text { - Flooding } & \begin{array}{l}\text { Pearl River Delta } \\ \text { (China) }\end{array} & \begin{array}{l}\text { Urbanisation and } \\ \text { ineffective land use } \\ \text { policy }\end{array}\end{array}$

- $\quad$ Lack of running piped water and waste collection
Ejisu (Ghana)

(Gha)

\author{
Urban sprawl due to \\ unregulated land \\ market, lack of urban \\ planning, and close \\ proximity to main city \\ of Kumasi
}

\author{
Increased runoff by \\ expanding built-up \\ land and displacing \\ farmland, causing \\ deforestation \\ Lack of urban public \\ services and \\ transportation \\ services in newly \\ emerging \\ neighbourhoods \\ (Du et al., 2015) \\ (Cobbinah and \\ Aboagye, 2017)
}

With overurbanisation, due to unemployment of migrants, the urban poor population often increases (Murayama et al., 2017), ending up clustered together in undesirable neighbourhoods in the urban area. This clustering process whereby people of a given socio-economic status tend to live together in the same neighbourhoods is called socioeconomic segregation. This becomes visible in the urban structure through residential differentiation, whereby rich people reside in expensive real estate and poor people live in more modest dwellings. However, in some cases, especially in neighbourhoods in transition, a mismatch between the residential characteristics and the socioeconomic group may occur. This is, for example, the case in upcoming neighbourhoods where rich people start buying real estate in formerly deprived urban areas. On the other hand, in declining neighbourhoods the original wealthier population may decide to move, after which their big houses are occupied by poorer people.

A high degree of socioeconomic segregation is considered problematic as it may lead to concentration of the poor in certain underserviced areas resulting in lock-in situations (Glebbeek and Koonings, 2015). Socioeconomic segregation has many causes, namely supply, demand, and institutional factors (Zhao, 2013). Supply factors relate to the supply of, for instance housing and other urban public services such as schools and infrastructure. Demand factors deal with residential preferences related to the socioeconomic characteristics of different groups (Bergström and van Ham, 2010, Timberlake, 2016). Institutional factors can relate to housing policies, zoning, and tenure laws (Muhammad et al., 2015, Adedire and Adegbile, 2017). For instance, the urban poor are often confined to slums due to limited social housing, household income, and the difficulty to obtain formal property rights. In turn, these slums lack educational and employment opportunities, further reinforcing the underprivileged status of the residents (Davis, 2016).

The dynamic process of socioeconomic segregation has been described for numerous cases in the developed world but are hitherto less studied in the cities of the Global South. This is rather problematic as most of these cities are characterised by very high growth rates and existing knowledge on socioeconomic segregation processes from the developed world are often not applicable in the Global South. While lately some cities of the Global North, such as in the Netherlands and Britain, are characterised by gentrification and a suburbanisation of poverty ( Hochstenbach and Musterd, 2017, Bailey and Minton, 2017), many poor dwellers are trapped in slums in the urban centres in developing countries (Vermeiren et al., 2016). The lack of urban expansion and socioeconomic segregation studies in the Global South can partially be attributed 
to the fact that very few data on these processes are being collected by local and national planning agencies due to insufficient finances, spatial data, and expertise (Elias et al., 2012, Inostroza et al., 2013, Ezquiaga Arquitectura, 2015).

Recently several satellite archives, both at medium and high resolution, became freely available thanks to the open access policy of a few major national mapping agencies (NASA) and private companies $\left(\mathrm{Google}^{\odot}\right)$. This open access policy may create new possibilities for analysing urban sprawl and socioeconomic segregation in developing countries. This paper evaluates to what extent it is possible to extract relevant information from these free sources for urban sprawl detection both in terms of spatial patterns and socioeconomic segregation. The Greater Paramaribo Region (GPR) in Suriname is used as a case study. The GPR is experiencing urban sprawl and its associated issues, all while coping with inadequate spatial planning and a lack of data, finances, technology, and expertise at the governmental level. The specific objectives of this research are:

- to determine the location, extent, and pattern of urban sprawl of the GPR using free Landsat satellite imagery.

- to analyse socioeconomic segregation processes within the GPR based on free Google Earth ${ }^{\odot}$ imagery.

\section{STUDY AREA}

The Republic of Suriname, at the north coast of South-America, with an area of $163,820 \mathrm{~km}^{2}$ of which more than $90 \%$ is forest, comprises 10 districts, divided into 62 municipalities. The GPR consists of the districts Paramaribo, Wanica, and a section of Commewijne. Total population in 2012 was 541,638, with the most densely populated districts being the capital Paramaribo and Wanica (General Bureau of Statistics Suriname, 2013). Between 2000 and 2015, the GPR experienced a population growth of $14 \%$, with the largest growth occurring in Wanica, within the municipality of Koewarasan $(\mathrm{KN})$, namely $111 \%$. The growth is largely due to the urban pull effect of the city on the rural population (General Bureau of Statistics Suriname, 2013). As affordable land within Paramaribo itself is lacking, people settle in the surrounding districts where free space is still available (Figure 1). These migration patterns cause the appearance of new urban areas and the outward expansion of old ones. This can be classified as urban sprawl, as expansion is often unplanned and uncontrolled by the government.

\section{[INSERT FIGURE 1 HERE]}

Within the GPR, the socioeconomic segregation effect of this sprawl has also been observed. Verrest (2010) stated that mainly socioeconomic status served as the basis for the spatial patterns in Paramaribo. During the 1950s, the poorer population could not afford to move to newly built suburbs with larger plot sizes, and therefore remained within the city, while the wealthier population left the inner city for the suburbs. Moreover, government-driven social housing projects 
have been established on former agriculture land at the fringe of the city. Projects established during the 1980s were mostly illegally occupied by the refugees fleeing the civil war. This illegal occupation due to migration of the poor rural population is still ongoing. These occupants are very poor and sometimes have no access to electricity or running water. They generally consist of multiple families occupying a single-family dwelling or have many small houses on one plot. These areas can be categorised as slums which, according to the Sustainable Development Goals indicator 11.1.1, lack one of the following basic services: access to improved water supply and sanitation, durable housing, sufficient living area, or tenure security. According to the United Nations Development Indicators Unit (2015), the proportion of urban population living in slums in Suriname increased from 3.9\% in 2005 to $7.3 \%$ in 2014. The National Development Plan of the government mentions the creation of an equal society regarding development, income, standard of living, and quality of life. Thus, in order to achieve this goal, information concerning the segregation among the population is required.

\section{MATERIALS AND METHODS}

Detection of urban sprawl in the GPR - Land use and land cover changes between 1987-2000 (period I) and 2000-2015 (period II) were assessed, based on the following free data: Landsat TM5, Landsat 7 ETM+, and Landsat 8 OLI Surface Reflectance Data Products (path 229, row 56) for the years 1987, 2000, and 2015 respectively, courtesy of the U.S. Geological Survey Earth Resources Observation and Science Center. The Data Products were geometrically and atmospherically corrected, with a $30 \mathrm{~m}$ resolution and a UTM-21N projection, and included cloud and cloudshadow masks. They have been found to increase the precision in mapping land cover (Feng et al., 2013, Vuolo et al., 2015) and have been used in a numerous studies (Fu et al., 2015, Ju and Masek, 2016, Haashemi et al., 2016). For gap filling, required after cloud and cloud-shadow removal, images within a maximum deviation of two years from the main dates, were collected as well.

Land use maps were created for the years 1987, 2000, and 2015 via a pixel-based, maximum likelihood supervised classification method. Identified classes were built-up (BU), nonbuilt-up (NBU), and Water. BU included residential, commercial, and industrial areas. The BU area of 1987 was imposed on the maps of 2000 and 2015, to ensure only BU growth assessment (Vermeiren et al., 2012). Classification accuracy was assessed via the overall accuracy and the Kappa Index of Agreement (KIA). Through stratified random sampling, 400 sample points were placed; 100 points in the class BU, 75 points in W, and 225 points in NBU. For the year 1987, the same Landsat image was used as reference data, as no free higher resolution satellite data was available. For 2000 and 2015, the same Landsat images used for the classification, were pansharpened using their $15 \mathrm{~m}$ resolution band. These were then used as higher resolution reference data for the accuracy assessment of classified maps. Pan-sharpening creates new images, which maintain the spectral information from the spectral bands, while increasing their resolution from $30 \mathrm{~m}$ to $15 \mathrm{~m}$ (Tapiador et al., 2011, Munyati et al., 2014). The overall accuracy of the different classified maps was calculated to be $96.8 \%, 92.8 \%$, and $95.5 \%$ for the years 1987, 2000, and 2015 
respectively. The KIA for the different years was $0.94,0.87$, and 0.92 respectively. These accuracy measures thus indicated that the classified maps were sufficiently accurate to be used in the further analysis.

Controlling factors of BU expansion and future BU area simulation - Via multiple logistic regression modelling, the influence of possible spatially explicit controlling factors on urban BU expansion for both periods was evaluated. Logistic regression relates expansion to the controlling factors of this expansion, based on past data (Atak et al., 2014). The controlling factors considered in this study are shown in Table 2.

Table 2: The different controlling factors which were used in the logistic regression analysis

\begin{tabular}{llll}
\hline Controlling factor & Acronym & Units & Data source \\
\hline 'distance_to_the_city_centre' & DC & kilometre & Digitised on developed land use map \\
'distance_to_roads' & DR & kilometre & Adapted from OpenStreetMap layer \\
( OpenStreetMap contributors) \\
'distance_to_previously_existing_BU_land' & DBU & kilometre & Developed land use map \\
'land_price' & LP & EURO $/ \mathrm{m}^{2}$ & MI-GLIS (2014) \\
'elevation' & EL & meter above sea level & USGS (2014) \\
'distance_to_social_housing' & DSH & kilometre & Mapped from secondary non-spatial \\
\end{tabular}

Similar controlling factors have been used in several studies regarding urban expansion (Poelmans and Van Rompaey, 2010, Kim et al., 2014, Li et al., 2015). Calibrating the logistic regression model was done in the $\mathrm{R}$ Studio $^{\odot}$ software using 1000 sampling points, randomly placed in the NBU area of the classified maps. This sample size corresponds with, on average 1 point every $\mathrm{km}$ resulting in an average distance between two sample points of circa $16 \mathrm{~km}$. The variograms of all predicting variables listed in Table 2, showed that the autocorrelation range never exceeds this distance, which allowed for unbiased parameter estimates.

For each sample point, data was extracted from the possible controlling factors and the maps of urban expansion created in the previous section. An iterative maximum likelihood procedure was then applied to assess the parameters of following equation:

$$
P(N B U \rightarrow B U)=\frac{e^{a+b_{1} D C+b_{2} D R+b_{3} D B U+b_{4} L P+b_{5} E L+b_{6} D S H}}{1+e^{a+b_{1} D C+b_{2} D R+b_{3} D B U+b_{4} L P+b_{5} E L+b_{6} D S H}}
$$

where $b_{1}, . ., b_{6}$ are the regression coefficients.

This equation was parametrised for period I (1987-2000) and period II (2000-2015) and probability values for all NBU pixels were assessed. McFadden's pseudo- $\mathrm{R}^{2}$ was calculated to evaluate the goodness of fit of the model, compared to the null model. Pseudo- $\mathrm{R}^{2}$ values between 0.2 and 0.4 are considered to indicate a good model fit (McFadden, 1977).

The predictive strength of the model was also determined by calculating the Relative Operating Characteristic curve, which compares the assessed probabilities with observed NBU to 
BU conversions (Pontius and Schneider, 2001). An Area Under the Curve (AUC) value of 1 indicates perfect spatial agreement between the probability map and the actual change. An AUC value $>0.75$ signifies a good fit of the model to the data (Chouvardas and Vrahnakis, 2009, Atak et al., 2014). Hereafter, future NBU to BU change was simulated for the year 2030 under a Business As Usual (BAU) scenario. Future demand for BU area was extrapolated, based on the BU expansion trend of period II. Based on the calculated transition probabilities, pixels with the highest probabilities were changed from NBU to BU, until the future BU demand was met.

Residential differentiation and socioeconomic segregation - Residential characteristics were used to gain insight into the socioeconomic status of the population (Munyati et al., 2014, Yang et al., 2016, Sun et al., 2017). Visual differentiation was based on five spatial residential characteristics (Table 3).

Table 3: Distinction between residential groups, based on spatial criteria

\begin{tabular}{lcccc}
\hline Criteria & Rich & Middle & Middle to low & Poor \\
\hline Average size of plot & $>600 \mathrm{~m}^{2}$ & $350<$ plot $<600 \mathrm{~m}^{2}$ & $300<$ plot $<350 \mathrm{~m}^{2}$ & $<300 \mathrm{~m}^{2}$ \\
Average size of house & $>300 \mathrm{~m}^{2}$ & $150<$ house $<300 \mathrm{~m}^{2}$ & $100<$ house $<150 \mathrm{~m}^{2}$ & $<100 \mathrm{~m}^{2}$ \\
Street type & Asphalt & Asphalt/ street tiles & Asphalt/ street tiles/sand & Sand (narrow)/ no street \\
Private swimming pool & $\checkmark$ & - & - & - \\
Clear demarcation of plot & $\checkmark$ & $\checkmark$ & $\checkmark$ & - \\
\hline
\end{tabular}

Based on these spatial characteristics, residences were divided into four groups: 1) Rich, 2) Middle, 3) Middle to low, and 4) Poor (mainly squatter settlements). Plot size for group 4 was set at maximum $300 \mathrm{~m}^{2}$, which was the minimum for group 3; this is the level set by the government for the social housing projects (Verrest, 2010). The Ministry of Public Works set the lower limit for private developments at $350 \mathrm{~m}^{2}$; this was used as the lower limit for a plot size for the Middle group. The Middle group is able to purchase land and/or a house through the bank at the standard loan rent percentage. Plots larger than $600 \mathrm{~m}^{2}$ belong to the richer population (de Brujine and Namdar, 2013). The house size criteria for groups 3 and 4 was set on levels applied by the Social Housing department of the government (Stichting Volkshuisvesting Suriname, 2016). Examples of each group can be seen in Figure 2.

\section{[INSERT FIGURE 2 HERE]}

Mapping residential differences required high-resolution satellite images. As these images are expensive to obtain, free DigitalGlobe QuickBird ${ }^{\odot}$ images, present in Google Earth ${ }^{\odot}$ were used. Their spatial resolution of $2.4 \mathrm{~m}$ was sufficient to identify smaller objects such as small buildings and pools, in order to differentiate between the residences. A similar usage of high resolution QuickBird images, to differentiate social classes in an urban setting was described by Avelar et al. (2009) and Munyati et al. (2014). These studies, however, obtained the images directly from the provider and not freely from Google Earth ${ }^{\odot}$. A study by Salvati et al. (2015) used high-resolution Google Earth ${ }^{\odot}$ imagery to analyse the correlation between identified pools and class segregation. 
Other studies visually interpreted Google Earth $^{\odot}$ to identify and delineate slums (Gunter, 2009, Krishna et al., 2014, Marghany and van Genderen, 2014).

Google Earth ${ }^{\odot}$ images contain only three visible bands. As such, they contain insufficient information for a pixel-based image classification. Thus, the Google Earth ${ }^{\odot}$ DigitalGlobe

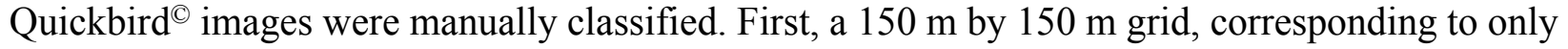
residential BU areas, was placed over the images. Secondly, each grid cell was assigned to a residential group, based on the five spatial characteristics of the residences within that grid. For example, in Figure 3a grid cell 1 had an average plot size of $2314 \mathrm{~m}^{2}$, an average house size of 587 $\mathrm{m}^{2}$, asphalt roads, pools, and plots were clearly demarcated. This grid cell was then assigned group 1 (Rich). Thirdly, the BU expansion maps of periods I and II, created in the urban expansion assessment, were overlaid on the grid (Figure $3 \mathrm{~b}$ ). This process allowed differentiating the BU expansion into the four different groups (Figure 3c).

\section{[INSERT FIGURE 3 HERE]}

Next, the compiled residential differentiation maps were used to assess the degree of segregation at the municipality level in the GPR. The districts Paramaribo, Commewijne, and Wanica consist of 12, 3, and 7 municipalities respectively. Segregation relates to the unequal distribution of different groups within an area (Massey and Denton, 1988). The most frequently used measure of segregation is the Dissimilarity Index (DI) (Reardon and Firebaugh, 2002, Farrell and Lee, 2011). The multigroup $\mathrm{DI}_{\mathrm{m}}$ can be used to assess the segregation of more than two residential types (and therefore socioeconomic types), in terms of land area (Sakoda, 1981, Sun et al., 2017). In this study, the $\mathrm{DI}_{\mathrm{m}}$ was used to assess the segregation of the four residential groups. The $\mathrm{DI}_{\mathrm{m}}$ is calculated as follows:

$$
D I_{m}=\frac{{ }_{1} \sum_{i-1}^{n} \sum_{j=1}^{n}\left|N_{i j}-E_{i j}\right|}{2 \sum_{j=1}^{n} N P_{j}\left(1-P_{j}\right)}, \text { with }
$$

Equation 2

$\mathrm{N}_{\mathrm{ij}}=$ area of a certain residential type $\mathrm{j}$ in municipality $\mathrm{i}$

$\mathrm{N}_{\mathrm{i}}=$ areas of all residential types municipality $\mathrm{i}$

$\mathrm{N}_{\mathrm{j}}=$ area of a certain residential type $\mathrm{j}$ in the GPR

$\mathrm{N}=$ area of all residential types in the GPR

$\mathrm{DI}_{\mathrm{m}}$ ranges from 0 to 1 . $\mathrm{DI}_{\mathrm{m}}$-values below 0.3 indicate a low level of segregation, while $\mathrm{DI}_{\mathrm{m}}$-values above 0.6 point at a high level of segregation.

\section{RESULTS AND DISCUSSION}

Urban expansion between 1987-2000 and 2000-2015 in the GPR - The total BU area in 1987 was $82 \mathrm{~km}^{2}$, of which $60 \%$ was located in district Paramaribo. BU area increased by $36 \mathrm{~km}^{2}$ and $51 \mathrm{~km}^{2}$ during periods I and II respectively, with district Wanica experiencing the most growth. 
During period I, both expansion of and infill growth within the existing BU area was observed. Period II was mainly characterised by the outward ribbon development, with infill growth being almost non-existent (Figure 4).

\section{[INSERT FIGURE 4 HERE]}

Controlling factors of BU expansion - During period I, 'distance_to_the_city_centre' was the most influential factor, followed by the 'distance_to_previously_existing_BU_land' (Table 4). New BU areas emerged within $5-10 \mathrm{~km}$ from the city centre and its urban services. In contrast, during period II 'distance_to_previously_existing_BU_land' became more significant, which is an indication of the sprawl effect. As land close to the city centre was already converted, BU expansion occurred further than $10 \mathrm{~km}$ away from the city centre. During both periods, 'distance_to_roads' was also significant. Newly emerging areas were located further from the city, their development depending on road access. Such development can be seen in Commewijne, where most of the expansion occurred after 2000, due to the construction of the Jules Wijdenbosch Bridge over the Suriname River (Figure 4). In addition, BU expansion was negatively correlated with 'land_price', with new BU areas emerging in more distant, cheaper municipalities.

For the two periods respectively, increasing 'distance_to_the_city_centre' by $1 \mathrm{~km}$, reduced the probability of NBU to BU change by $12 \%$ and $11 \%$. Enlarging the 'distance_to_previously_existing_BU_land' by $1 \mathrm{~km}$, resulted in a decrease of NBU to BU change of $92 \%$ and $96 \%$. Expanding the 'distance_to_roads' by $1 \mathrm{~km}$, lowered the probability by $74 \%$ and $63 \%$. Raising 'land_price' $1 \mathrm{EURO} / \mathrm{m}^{2}$ also reduced the chance of urban expansion by $2 \%$. Increasing 'elevation' by $1 \mathrm{~m}$ reduced the chance on urban expansion by $1 \%$ during the first period, but increased the chance in the second period by $2 \%$. This implies that the earlier urban expansion (1987-2000) avoided low-lying, flood prone zones, while the recent urban growth (2000-2015) involved higher flood risk.

Table 4: Calibrated logistic regression model coefficients

\begin{tabular}{|c|c|c|c|c|c|c|c|c|}
\hline & \multicolumn{4}{|c|}{$\begin{array}{c}1987-2000 \text { (period I) } \\
\text { McFadden's } R^{2}=0.28\end{array}$} & \multicolumn{4}{|c|}{$\begin{array}{l}2000-2015(\text { period II) } \\
\text { McFadden's } R^{2}=0.29\end{array}$} \\
\hline & Coefficient & P-value & & $\begin{array}{l}\text { Odds } \\
\text { Ratio }\end{array}$ & Coefficient & P-value & & $\begin{array}{l}\text { Odds } \\
\text { Ratio }\end{array}$ \\
\hline (Intercept) & 2.036 & 0.00000115 & $* * *$ & & 2.067 & 0.0000000129 & $* * *$ & \\
\hline DC & -0.128 & 0.00000126 & $* * *$ & 0.88 & -0.1129 & 0.000000346 & $* * *$ & 0.89 \\
\hline DR & -1.348 & 0.00780000 & $* *$ & 0.26 & -1.002 & 0.000889 & $* * *$ & 0.37 \\
\hline DBU & -2.559 & 0.00007930 & $* * *$ & 0.08 & -3.122 & 0.0000000018 & $* * *$ & 0.04 \\
\hline $\mathbf{L P}$ & -0.01718 & 0.07928000 & . & 0.98 & -0.01853 & 0.059316 & . & 0.98 \\
\hline EL & -0.1076 & 0.00161000 & $* *$ & 0.90 & 0.01512 & 0.470299 & n.s. & 1.02 \\
\hline
\end{tabular}

Based on these identified significant factors, logistic regression models were developed. To assess the accuracy of the models, AUC values were calculated. AUC values of 0.853 and 0.825 for periods I and II respectively, indicate that these significant factors can be used to simulate future change from NBU to BU. The probability of change from NBU to BU was calculated for both 
periods, according to equation 1, with the coefficients shown in Table 4 . The probability map for period II is shown in Figure 5a. Following the period II trend of NBU to BU change, BU area in 2030 was calculated to be $251 \mathrm{~km}^{2}$, signifying a growth of $49 \%$ between $2015-2030$ (Figure $5 \mathrm{~b}$ ). A continuation of the spatial pattern of urban expansion is seen, with new BU ribbon development expanding outward from the previously BU area towards the south of the GPR, while still attempting to be close to the urban city centre.

\section{[INSERT FIGURE 5 HERE]}

Residential differentiation and socioeconomic segregation in the GPR - In 1987, $69 \mathrm{~km}^{2}$ of the $82 \mathrm{~km}^{2}$ of BU area was residential. The largest residential group in 1987 was Middle to low, followed by Middle, Rich, and Poor. From 1987 until 2015, residential BU area expanded by 71 $\mathrm{km}^{2}$ (Table 5). During the entire study period, Middle and Middle to low expanded the most. During period I, the expansions of Middle and Middle to low were almost equal, while during period II, the expansion of Middle was larger than Middle to low. We can also see an increased growth of Poor residential areas, which was almost two and a half times larger than during period I.

Table 5: Expansion in $\mathrm{km}^{2}$ of the different groups, per district per time period

\begin{tabular}{lcrcr|rrrrrr}
\hline & \multicolumn{4}{c|}{ Expansion $\left(\mathbf{k m}^{\mathbf{2}}\right)$ period I } & \multicolumn{5}{c}{ Expansion (km²) period II } \\
District & Rich & Middle & Middle to low & Poor & Total & Rich & Middle Middle to low & Poor & Total \\
\hline Paramaribo & 1.62 & 4.92 & 3.63 & 0.46 & 10.63 & 1.39 & 6.22 & 3.00 & 0.98 & 11.59 \\
Wanica & 0.44 & 7.83 & 8.39 & 0.07 & 16.73 & 0.90 & 12.92 & 9.94 & 0.30 & 24.05 \\
Commewijne & 0.15 & 0.84 & 1.40 & 0.04 & 2.43 & 0.27 & 1.55 & 3.16 & 0.05 & 5.03 \\
\hline \multicolumn{1}{c}{ Total } & 2.21 & 13.60 & 13.42 & 0.57 & 29.80 & 2.56 & 20.68 & 16.10 & 1.33 & 40.67 \\
\hline
\end{tabular}

Paramaribo had the largest growth of Rich residential area in both periods, which occurred mainly in the municipality Blauwgrond (BD). Latour (LR) had the most expansion of Poor areas during both periods (Figure 6). These municipalities could also be classified as the richest and the poorest, when assessing socioeconomic information (employment and education rates) found in the census data. This supports our findings, thus providing a correlation between the spatial residential characteristics and a specific socioeconomic group. Middle residences also expanded mainly in BD during period I. In period II, Middle and Middle to low residences made up most of the residential BU area in Wanica. The largest expansion of Middle to low residences occurred in De Nieuwe Grond (DD).

\section{[INSERT FIGURE 6 HERE]}

A certain level of segregation of the different residential groups could be discerned within the GPR. From Table 6, the $\mathrm{DI}_{\mathrm{m}}$ of around 0.30 for the GPR as a whole, indicates a low segregation or a heterogeneous area throughout the study period. At district level, both Paramaribo and Commewijne had slightly moderate segregation between residence types $\left(\mathrm{DI}_{\mathrm{m}}>0.3\right)$, while Wanica 
had the lowest segregation $\left(\mathrm{DI}_{\mathrm{m}}<0.3\right)$ between groups. Looking at the indices per residential group, it is clear that Rich and Poor residences are unevenly distributed throughout the GPR, as indicated by their values of $>0.5$. These residences are more concentrated in certain areas (Figure 6). The Poor were the most segregated, according to their higher $\mathrm{DI}_{\mathrm{m}}$ value. Compared to other studies, Sun et al. (2017) found similar $\mathrm{DI}_{\mathrm{m}}$ values for Rich $(>0.5)$ and Poor $(>0.6)$ residences in 2014 on Xiamen Island, China. Another study, of Hong Kong, also found that the Rich were the most segregated group between 1999 and 2007 (>0.55); however, the poorest households were more evenly distributed $(<0.3)$ (Yip, 2012).

Table 3: Generalised dissimilarity indices for the different residential groups and the GPR as a whole

\begin{tabular}{lcccc|cccc}
\hline & Rich & Middle & Middle to low & Poor & Paramaribo & Wanica & Commewijne & GPR \\
\hline $\mathbf{D I}_{\mathbf{m}} \mathbf{1 9 8 7}$ & 0.51 & 0.28 & 0.30 & 0.66 & 0.38 & 0.16 & 0.33 & 0.32 \\
$\mathbf{D I}_{\mathbf{m}} \mathbf{2 0 0 0}$ & 0.50 & 0.25 & 0.29 & 0.64 & 0.37 & 0.16 & 0.32 & 0.30 \\
$\mathbf{D I}_{\mathbf{m}} \mathbf{2 0 1 5}$ & 0.51 & 0.23 & 0.28 & 0.68 & 0.35 & 0.18 & 0.29 & 0.29 \\
\hline
\end{tabular}

When comparing only the Rich vs the Poor residential groups, the $\mathrm{DI}_{\mathrm{m}}$ of the GPR equalled 0.84 in 2000 and 0.87 in 2015, indicating an increasing segregation between these two groups (Table 7). Compared to other regions, such as the United States, Britain, and Europe, the Rich-Poor segregation in the GPR is high. However, as the $\mathrm{DI}_{\mathrm{m}}$ is scale dependent, the higher indices could be due to the smaller scale. Not only do regions differ in scale, but also in context. We therefore consider the change in $\mathrm{DI}_{\mathrm{m}}$, when comparing regions (Ismail, 2013). Segregation between Rich and Poor in the GPR increased with $0.2 \%$ per year but occurred at a lower rate, compared with Madrid, Oslo, and New York (Table 7). The GPR-evolutions therefore seem to follow the pattern of US cities more closely than European cities.

Table 7: Rich-Poor dissimilarity index of the GPR, compared to other cities

\begin{tabular}{lcc|cccc}
\hline Area & Year & $\begin{array}{c}\text { Rich vs Poor } \\
\mathbf{D I}_{\mathbf{m}}\end{array}$ & Year & $\begin{array}{c}\text { Rich vs Poor } \\
\mathbf{D I}_{\mathbf{m}}\end{array}$ & $\begin{array}{c}\text { Annual change in } \\
\text { Rich vs Poor DI }_{\mathbf{m}} \\
\mathbf{( \% )}\end{array}$ & Source \\
\hline GPR & 2000 & 0.84 & 2015 & 0.87 & 0.2 & (Bailey and Minton, 2017) \\
British cities & 2004 & 0.36 & 2015 & 0.32 & -1.0 & (Musterd et al., 2016) \\
Amsterdam & 2001 & $\approx 0.38$ & 2011 & $\approx 0.34$ & -1.1 & (Musterd et al., 2016) \\
Madrid & 2001 & $\approx 0.37$ & 2011 & $\approx 0.49$ & 3.2 & (Musterd et al., 2016) \\
Oslo & 2001 & $\approx 0.21$ & 2011 & $\approx 0.23$ & 1.0 & (Kucheva, 2013) \\
Los Angeles & 2000 & 0.34 & 2009 & 0.34 & 0.0 & (Kucheva, 2013) \\
New York & 2000 & 0.34 & 2009 & 0.36 & 0.7 & (Kucheva, 2013) \\
Chicago & 2000 & 0.41 & 2009 & 0.38 & -0.8 & \\
\hline
\end{tabular}

Controlling factors of residential BU expansion -Logistic regression, using 1000 sampling points, was applied to assess the different controlling factors for their influence, now on the expansion per residential group for period II (Table 8). Probability maps were created (Figure 7), with AUC values of 0.83, 0.82, 0.82, and 0.95, for the groups Rich, Middle, Middle to low, and Poor respectively. The Poor model has the highest McFadden's $\mathrm{R}^{2}$, implying an accurate model. This indicates that the poorer residential groups tend to behave more predictably than richer 
groups, possibly as their opportunities are more limited. For the other groups, the models were not as accurate, but still significantly better than a random model. The Middle to low model had the lowest McFadden's $\mathrm{R}^{2}$, indicating a weak model.

Rich area expansion was mostly influenced by the 'distance_to_the_city_centre' and 'land_price', occurring mainly within the higher priced municipalities in Paramaribo. Raising the price by $1 E U R O / \mathrm{m}^{2}$, increased Rich expansion by $6 \%$. Expanding 'distance_to_the_city_centre' by $1 \mathrm{~km}$, decreased Rich expansion by $18 \%$. Growth of Middle areas occurred as ribbon development, preferably still close to the city centre. Enlarging the 'distance_to_previously_existing_BU_land' and 'distance_to_roads' by $1 \mathrm{~km}$, lowered the probability of Middle expansion by $96 \%$ and $68 \%$, respectively. Expansion of Middle to low areas occurred mainly around the previously BU area, close to social housing projects. Increasing 'distance_to_previously_existing_BU_land' and 'distance to_social_housing' by $1 \mathrm{~km}$, reduced the probability of Middle to low expansion by $78 \%$ and $12 \%$ respectively. Poor areas expanded mainly around the social housing projects, within $15 \mathrm{~km}$ from the city centre and where the land prices were lower. Increasing the 'distance_to_the_city_centre' by $1 \mathrm{~km}$, lessened the chance of Poor expansion by $26 \%$. A price raise of $1 \mathrm{EURO} / \mathrm{m}^{2}$, decreased Poor expansion by $15 \%$. Extending 'distance_to_social_housing' by $1 \mathrm{~km}$, diminished Poor expansion by 69\%. Aside from these housing market limitations, this congregation of new Poor around the social housing projects can also be due to a specific survival strategy of the Poor. They often have family members already living in the area with the same social and cultural background. These elements provide a feeling of familiarity and safety for newcomers (Johnston et al., 2016, Andersen, 2017, Aradhya et al., 2017). While elevation was not significant according to the p-values of the regression coefficients, increasing the elevation increased the odds of Rich and Middle expansion, while it decreased the odds of Middle to low and Poor expansion, signifying that poorer people are more likely to occur in lower lying, possibly undesirable areas.

Table 8: Logistic regression coefficients per group

\begin{tabular}{|c|c|c|c|c|c|c|c|c|c|c|c|c|}
\hline \multirow{3}{*}{$\begin{array}{l}\text { Observations } \\
\text { McFadden's R }\end{array}$} & \multicolumn{3}{|c|}{ Rich expansion } & \multicolumn{3}{|c|}{ Middle expansion } & \multicolumn{3}{|c|}{ Middle to low expansion } & \multicolumn{3}{|c|}{ Poor expansion } \\
\hline & \multicolumn{3}{|c|}{$\begin{array}{r}23 \\
0.22\end{array}$} & \multicolumn{3}{|c|}{$\begin{array}{c}137 \\
0.24\end{array}$} & \multicolumn{3}{|c|}{$\begin{array}{c}67 \\
0.16\end{array}$} & \multicolumn{3}{|c|}{$\begin{array}{c}9 \\
0.51\end{array}$} \\
\hline & Coefficient & & $\begin{array}{l}\text { Odds } \\
\text { Ratio }\end{array}$ & Coefficient & & $\begin{array}{l}\text { Odds } \\
\text { Ratio }\end{array}$ & Coefficient & & $\begin{array}{l}\text { Odds } \\
\text { Ratio }\end{array}$ & Coefficient & & $\begin{array}{l}\text { Odds } \\
\text { Ratio }\end{array}$ \\
\hline (Intercept) & -2.87852 & $* *$ & & -0.47155 & n.s. & & -1.444253 & & & 4.7145 & $*$ & \\
\hline DC & -0.19495 & $*$ & 0.82 & -0.07023 & • & 0.93 & 0.023285 & n.s. & 1.02 & -0.29979 & $*$ & 0.74 \\
\hline DR & -0.39761 & n.s. & 0.67 & -1.13732 & $* * *$ & 0.32 & -0.388793 & n.s. & 0.68 & 0.44955 & n.s. & 1.57 \\
\hline DBU & -1.25011 & • & 0.29 & -3.34025 & $* * *$ & 0.04 & -1.521762 & $* *$ & 0.22 & -16.2912 & n.s. & 0 \\
\hline $\mathbf{L P}$ & 0.05577 & $* *$ & 1.06 & 0.01346 & n.s. & 1.01 & -0.004512 & n.s. & 1 & -0.16643 & . & 0.85 \\
\hline $\mathbf{E L}$ & 0.05213 & n.s. & 1.05 & 0.02556 & n.s. & 1.03 & -0.028646 & n.s. & 0.97 & -0.22057 & n.s. & 0.8 \\
\hline DSH & -0.01435 & n.s. & 0.99 & -0.02611 & n.s. & 0.97 & -0.123909 & $*$ & 0.88 & -1.16156 & $* *$ & 0.31 \\
\hline
\end{tabular}

[INSERT FIGURE 7 HERE] 
In the BAU simulation for 2030 based on the developed probability maps, Rich, Middle, and Middle to low residences will likely grow by $28 \%, 57 \%$, and $23 \%$ respectively. Poor residences will grow by $84 \%$ between 2015 and 2030, continuing the trend of having the highest growth rate of the groups (Figure 8). Segregation, especially between the Rich and Poor is expected to continue. The $\mathrm{DI}_{\mathrm{m}}$ 's calculated for 2030 for Rich, Middle, Middle to low, and Poor residences are $0.54,0.26,0.25$, and 0.73 respectively. The GPR as a whole, will have a $\mathrm{DI}_{\mathrm{m}}$ of 0.3 , indicating an overall low segregation between the residential groups, and thus between the socioeconomic groups.

\section{[INSERT FIGURE 8 HERE]}

\section{CONCLUSION}

This study demonstrated the possibility to determine location, extent, and pattern of urban sprawl in the GPR with free $30 \mathrm{~m}$ resolution Landsat satellite images. Furthermore, a built-up expansion logistic regression model was created to evaluate different spatial controlling factors of this expansion. The most significant factors throughout the years were 'distance_to_previously_existing_BU_land', 'distance_to_the_city_centre', and 'distance_to_roads'. These clearly determine the pattern of urban sprawl, with BU ribbon development expanding outward from older BU areas around the city centre. The expansion model was also used to simulate future BU growth in a BAU simulation. This future landscape foresees BU expansion continuing towards the south of Wanica, leading further away from the city centre and all its services. The developed expansion model can contribute to more efficient and effective spatial planning in Suriname. Land use conflicts can be avoided, underserviced areas can be identified beforehand, and effective spatial plans can be developed to manage urban sprawl.

In addition, this study assessed the residential differentiation among the residences within in the GPR. This assessment was then used to gain insight into the socioeconomic segregation among the population. The characteristics used in this study proved sufficient to differentiate between four residential groups, namely Rich, Middle, Middle to low, and Poor. The calculated dissimilarity indices indicate a large segregation between Rich and Poor residences, and thus between Rich and Poor socioeconomic groups, each of which are concentrated in different neighbourhoods. Simulations, based on logistic regression equations, indicate that as the city expands, this socioeconomic segregation is expected to remain very high. The Rich vs Poor dissimilarity values detected in this study are much higher than those reported for European and North-American cities. Further research in developing countries could reveal whether this is a general characteristic of rapidly growing cities in developing countries. Future planning policies should aim at lowering the segregation level in the GPR as it leads to social injustice for the deprived social groups. These groups are often trapped in underserviced areas with poor accessibility to government services and utilities such as schools, medical centres, tap water, sewage systems, and paved roads. 
This study showed that free spatial data sources such as Google Earth are very useful for mapping and analysing residential differentiation and socioeconomic segregation. We would therefore recommend that urban planning services in developing countries, operating on limited budgets, would start building datasets based on these open source data, which could lead to more sustainable planning practices, benefitting the entire population in the long term.

\section{REFERENCES}

Adedire, F. M. and Adegbile, M. B. O. (2017) 'Factors Influencing Housing Characteristics in Lagos Peripheral Settlements: Case of Ikorodu', Architecture Research, 7(5), pp. 10.

AndERSEN, H. S. (2017) 'Selective moving behaviour in ethnic neighbourhoods: white flight, white avoidance, ethnic attraction or ethnic retention?', Housing Studies, 32(3), pp. 296-318.

AradhyA, S., Hedefalk, F., Helgertz, J. and Scott, K. (2017) 'Region of Origin: Settlement Decisions of Turkish and Iranian Immigrants in Sweden, 1968-2001', Population, Space and Place, 23(4), pp. e2031-n/a.

AtaK, B. K., Erdogan, N., Ersoy, E. and Nurlu, E. (2014) 'Analysing the spatial urban growth pattern by using logistic regression in Didim District', Journal of environmental protection and ecology, 15(4), pp. 1866-1876.

Avelar, S., Zah, R. and Tavares-Corrêa, C. (2009) 'Linking socioeconomic classes and land cover data in Lima, Peru: Assessment through the application of remote sensing and GIS', International Journal of Applied Earth Observation and Geoinformation, 11, pp. 27-37.

BAILEY, N. and Minton, J. (2017) 'The suburbanisation of poverty in British cities, 2004-16: extent, processes and nature ', Urban Geography, pp. 25.

Bergström, L. and van Ham, M. (2010) 'Understanding Neighbourhood Effects: Selection Bias and Residential Mobility', IDEAS Working Paper Series from RePEc.

BhatтA, B. (2010) Analysis of urban growth and sprawl from remote sensing data.: Springer Science \& Business Media.

Chauvin, J. P., Glaeser, E., Ma, Y. and Tobio, K. (2017) 'What is different about urbanization in rich and poor countries? Cities in Brazil, China, India and the United States', Journal of Urban Economics, (98), pp. 17-49.

Chouvardas, D. and Vrahnakis, M. S. (2009) 'A semi-empirical model for the near future evolution of the lake Koronia landscape', Journal of Environmental Protection and Ecology, 10(3), pp. 867-876.

Cobbinah, P. B. and Aboagye, H. N. (2017) 'A Ghanaian twist to urban sprawl', Land Use Policy, 61, pp. 231-241.

DAVIS, D. E. (2016) 'Reflections on the relations between development and urbanization: past trajectories and future challenges ', International Journal of Urban Sciences, 20(1), pp. 114.

De Brujine, A. and Namdar, A. 'Closer and closer to the Ocean. The Habitat and Housing structure of present day Paramaribo and the policies formulated for the near future - how to realize a sustainable city?', Caribbean Urban Forum 2013, Paramaribo.

DeVelopment Indicators Unit, S. D., United Nations (2015) United Nations site for the MDG Indicators. Available at: http://mdgs.un.org/unsd/mdg/Data.aspx (Accessed: 19 October 2016). 
Du, S., Shi, P. and Van Rompaey, A. (2014) 'The Relationship between Urban Sprawl and Farmland Displacement in the Pearl River Delta, China', Land, 3, pp. 34-51.

Du, S., Van Rompaey, A., Shi, P. and Wang, J. a. (2015) 'A dual effect of urban expansion on flood risk in the Pearl River Delta (China) revealed by land-use scenarios and direct runoff simulation', Natural Hazards, 77(1), pp. 111-128.

Elias, P., Dekolo, S. and Babatola, O. (2012) 'Land use change modelling in developing countries: issues and prospects', International Journal of Geography and Geology, 1(1), pp. 23-41.

Ezquiaga ARquitectura, S. y. T. S. L. (2015) 'The Experience of Latin America and the Caribbean in Urbanization. Knowledge Sharing Forum on Development Experiences: Comparative Experiences of Korea and Latin America and the Caribbean', Knowledge and Learning Sector \& Emerging and Sustainable Cities Initiative, pp. 30, Available: InterAmerican Development Bank.

FARrell, C. R. and Lee, B. A. (2011) 'Racial Diversity and Change in Metropolitan Neighborhoods', Social Science Research, 40(4), pp. 1108-1123.

Feng, M., Sexton, J., Huang, C., Masek, J., Vermote, E., Gao, F., Narasimhan, R., Channan, S., Wolfe, R. and Townshend, J. (2013) 'Global surface reflectance products from Landsat: Assessment using coincident MODIS observations', Remote Sensing of Environment, 134, pp. 276-293.

FU, D., Zhang, L., Wang, J., Sun, X. and Wu, T. (2015) 'Assessing the Effect of Temporal Interval Length on the Blending of Landsat-MODIS Surface Reflectance for Different Land Cover Types in Southwestern Continental United States', ISPRS International Journal of GeoInformation, 4, pp. 2542-2560.

General BUREAU OF STATISTICS SURINAME (2013) Suriname census 2012- Volume 1: Demografische en Sociale Karakteristieken en Migratie, Paramaribo2013-05).

GlebbeeK, M.-L. and Koonings, K. (2015) 'Between Morro and Asfalto. Violence, insecurity and socio-spatial segregation in Latin American cities', Habitat International, pp. 1-7.

Gollin, D., Jedwab, R. and Vollrath, D. (2016) 'Urbanization with and without industrialization', Journal of Economic Growth, 21(1), pp. 35-70.

GunTER, A. W. 'Getting it for free: Using Google earth ${ }^{\mathrm{TM}}$ and IL WIS to map squatter settlements in Johannesburg', 2009 IEEE International Geoscience and Remote Sensing Symposium, Cape Town, South Africa: IEEE, 388-391.

HaAshemi, S., Weng, Q., Darvishi, A. and Alavipanah, S. (2016) 'Seasonal Variations of the Surface Urban Heat Island in a Semi-Arid City', Remote Sensing, 8(4), pp. 17.

HochstenBACH, C. and Musterd, S. (2017) 'Gentrification and the suburbanization of poverty: changing urban geographies through boom and bust periods ', Urban Geography 39(1), pp. 26-53.

Inostroza, L., Baur, R. and Csaplovics, E. (2013) 'Urban sprawl and fragmentation in Latin America: A dynamic quantification and characterization of spatial patterns', Journal of Environmental Management, 115, pp. 87-97.

Ismail, A. (2013) 'The hybrid outcome of urban change: global city, polarized city?', Glocalism. Journal of Culture, Politics and Innovation, (1).

JEDWAB, R. and Vollrath, D. (2015) 'Urbanization without growth in historical perspective', Explorations in Economic History, (58), pp. 1-21.

Johnston, R., Poulsen, M. and Forrest, J. (2016) 'Ethnic Residential Patterns in Urban England and Wales, 2001-2011: A System-Wide Analysis', Tijdschrift voor economische en sociale geografie, 107(1), pp. 1-15. 
JU, J. and Masek, J. (2016) 'The vegetation greenness trend in Canada and US Alaska from 19842012 Landsat data', Remote Sensing of Environment, 176, pp. 1-16.

Khan, A. A., Arshad, S. and Mohsin, M. (2014) 'Population Growth and Its Impact on Urban Expansion: A Case Study of Bahawalpur, Pakistan', Universal Journal of Geoscience, 2(8), pp. 229-241.

KIM, I., Le, Q. B., Park, S. J., Tenhunen, J. and Koellner, T. (2014) 'Driving Forces in Archetypical Land-Use Changes in a Mountainous Watershed in East Asia', Land, 3, pp. 957-980.

Krishna, A., Sriram, M. S. and Prakash, P. (2014) 'Slum types and adaptation strategies: identifying policy-relevant differences in Bangalore', Environment \& Urbanization, 26(2), pp. 568-585.

Kucheva, Y. A. (2013) 'Subsidized Housing and the Concentration of Poverty, 1977-2008: A Comparison of Eight U.S. Metropolitan Areas ', City \& Community, 12(2), pp. 113-133.

LI, Q., Fang, C., Li, G. and Ren, Z. (2015) 'Quantitative Measurement of Urban Expansion and Its Driving Factors in Qingdao: An Empirical Analysis Based on County Unit Data', Journal of Resources and Ecology, 6(3), pp. 172-179.

MANAGEMENT INSTITUUT VOOR GRONDREGISTRATIE EN LAND INFORMATIE SYSTEEM (MI-GLIS) (2014) 'MI-GLIS Klapper Kaart. Gemiddelde Euro kale grondwaarde per vierkante meter'. Available

at: https://www.arcgis.com/home/item.html?id=369bc6002cc64c8fb5aa34639735eef4 (Accessed: 2015).

Marghany, M. and van Genderen, J. 'Three-dimensional slum urban reconstruction in Envisat and Google Earth Egypt ', IOP Conference Series: Earth and Environmental Science (EES), Kuching, Sarawak, Malaysia: 10.1088/1755-1315/18/1/012166.

Massey, D. S. and Denton, N. A. (1988) 'The Dimensions of Residential Segregation', Social Forces, 67(2), pp. 36.

MCFADDEN, D. 1977. Quantitative methods for analyzing travel behaviour of individuals: some recent developments. Cowles Foundation Discussion Paper no. 474. Connecticut: Cowles Foundation for research in economics.

MCGRANAHAN, G. and Satterthwaite, D. (2014) Urbanisation concepts and trends: IIED Working Paper. IIED, London.

Munammad, M. S., Kasim, R. and Martin, D. (2015) 'An Evaluation of Factors Influencing Residential Segregation in Selected Areas of Bauchi Metropolis, Northern Nigeria ', Mediterranean Journal of Social Sciences, 6(2), pp. 14.

Munyati, C., Motholo, G. L. and T (2014) 'Inferring urban household socio-economic conditions in Mafikeng, South Africa, using high spatial resolution satellite imagery', Urban, Planning and Transport Research, 2(1), pp. 51-71.

Murayama, Y., Kamusoko, C., Yamashita, A. and Estoque, R. C. (2017) 'Rapid Urbanization in Developing Asia and Africa ', Urban Development in Asia and Africa The Urban Book Series. 1 ed: Springer Nature Singapore Pte Ltd.

Musterd, S., Marcińczak, S., van Ham, M. and Tammaru, T. (2016) 'Socioeconomic segregation in European capital cities. Increasing separation between poor and rich', Urban Geography, 38(7), pp. 1062-1083.

PANDEY, B. and Seto, K. C. (2015) 'Urbanization and agricultural land loss in India: Comparing satellite estimates with census data', Journal of Environmental Management, 148, pp. 5366. 
Poelmans, L. and Van Rompaey, A. (2010) 'Complexity and performance of urban expansion models', Computers, Environment and Urban Systems, 34, pp. 17-27.

Pontius, R. G. J. and Schneider, L. C. (2001) 'Land-cover change model validation by an ROC method for the Ipswich watershed, Massachusetts, USA', Agriculture, Ecosystems and Environment, 85, pp. 239-248.

Ramachandra, T., Aithal, B. H. and Sanna, D. D. (2012) 'Insights to urban dynamics through landscape spatial pattern analysis', International Journal of Applied Earth Observation and Geoinformation, 18, pp. 329-343.

Reardon, S. F. and Firebaugh, G. (2002) 'Measures of Multigroup Segregation', Sociological Methodology, 32(1), pp. 33-67.

SAKODA, J. M. (1981) 'A Generalized Index of Dissimilarity', Demography, 18(2), pp. 245-250.

Salvati, L., Ridolfi, E., Saurí Pujol, D. and Serra Ruiz, P. (2015) 'Latent sprawl, divided Mediterranean landscapes: urban growth, swimming pools, and the sociospatial structure of Athens, Greece ', Urban Geography, pp. 17.

STICHTING VOLKSHUISVESTING SURINAME (2016) Financieringsmodaliteit. Available at: http://www.stichting-volkshuisvesting-suriname.org/financiering-entoewijzing/financieringsmodaliteit/ (Accessed: 19 October 2016).

Sun, C., Lin, T., Zhao, Y., Lin, M. and Yu, Z. (2017) 'Residential Spatial Differentiation Based on Urban Housing Types-An Empirical Study of Xiamen Island, China', Sustainability, 9(10), pp. 1777.

TAcoli, C., McGranahan, G. and Satterthwaite, D. (2015) Urbanisation, rural-urban migration and urban poverty., London. Available at: http://pubs.iied.org/10725IIED.

TAPiAdOR, F. J., Avelar, S., Tavares-Corrêa, C. and Zah, R. (2011) 'Deriving fine-scale socioeconomic information of urban areas using very high-resolution satellite imagery', International Journal of Remote Sensing, 32(21), pp. 6437-6456.

Timberlake, J. M. (2016) 'Residential Segregation', in Stone, J., Dennis, R.M., Rizova, P.S., Smith, A.D. \& Hou, X. (eds.) The Wiley Blackwell Encyclopedia of Race, Ethnicity, and Nationalism. 1 ed: JohnWiley \& Sons, Ltd.

U.S. GeOlogicAl SURVeY (USGS), N. G.-I. A. N. and National Aeronautics and Space Administration (NASA) (2014) 'Shuttle Radar Topography Mission 1 Arc-Second Global: SRTM1N05W056V3' (Version SRTM 1 Arc-Second Global). Available at: https://1ta.cr.usgs.gov/SRTM1Arc (Accessed: 2015).

United nations, D. o. E. a. S. A., Population Division (2014a) 'World Urbanization Prospects: The 2014 Revision, CD-ROM Edition. POP/DB/WUP/Rev.2014/1/F18' (Accessed.

United nations, D. o. E. a. S. A., Population Division (2014b) 'World Urbanization Prospects: The 2014 Revision, CD-ROM Edition. POP/DB/WUP/Rev.2014/1/F19'.

VAN LIDTH DE JEUde, M., Schütte, O. and Quesada, F. (2016) 'The vicious circle of social segregation and spatial fragmentation in Costa Rica's greater metropolitan area', Habitat International, (54), pp. 65-73.

VAZ, E. (2014) 'Managing urban coastal areas through landscape metrics: An assessment of Mumbai's mangrove system', Ocean \& Coastal Management, (98), pp. 27-37.

Vermeiren, K., Van Rompaey, A., Loopmans, M., Serwajja, E. and Mukwaya, P. (2012) 'Urban growth of Kampala, Uganda: Pattern analysis and scenario development', Landscape and Urban Planning, 106, pp. 199- 206. 
Vermeiren, K., Vanmaercke, M., Beckers, J. and Van Rompaey, A. (2016) 'ASSURE: a model for the simulation of urban expansion and intra-urban social segregation ', International Journal of Geographical Information Science.

Vermeiren, K., Verachtert, E., Kasaija, P., Loopmans, M., Poesen, J. and Van Rompaey, A. (2015) 'Who could benefit from a bus rapid transit system in cities from developing countries? A case study from Kampala, Uganda', Journal of Transport Geography 47, (47), pp. 13-22.

Verrest, H. J. L. M. (2010) 'City Profile: Paramaribo', Cities, 27, pp. 50-60.

Vuolo, F., Mattiuzzi, M. and Atzberger, C. (2015) 'Comparison of the Landsat Surface Reflectance Climate Data Record (CDR) and manually atmospherically corrected data in a semi-arid European study area', International Journal of Applied Earth Observation and Geoinformation, 42, pp. 1-10.

YANG, J., Sun, J., Zhao, H., Xi, J. and Li, X. (2016) 'Spatio-temporal Differentiation of Residential Land for Coastal Town: A Case Study of Dalian Jinshitan ', Chinese Geographical Science, 26(4), pp. 566-576.

Yue, W., Liu, Y. and Fan, P. (2013) 'Measuring urban sprawl and its drivers in large Chinese cities: The case of Hangzhou', Land Use Policy, 31, pp. 358-370.

ZHAO, P. (2013) 'The impact of urban sprawl on social segregation in Beijing and a limited role for spatial planning', Tijdschrift voor Economische en Sociale Geografie, 104(5), pp. 571587. 
Figure 1: Percent population change between 2000 and 2015 in municipalities of districts Paramaribo,
Wanica, and Commewijne

Figure 1: Percent population change between 2000 and 2015 in municipalities of districts Paramaribo,
Wanica, and Commewijne $290 \times 190 \mathrm{~mm}(300 \times 300$ DPI $)$

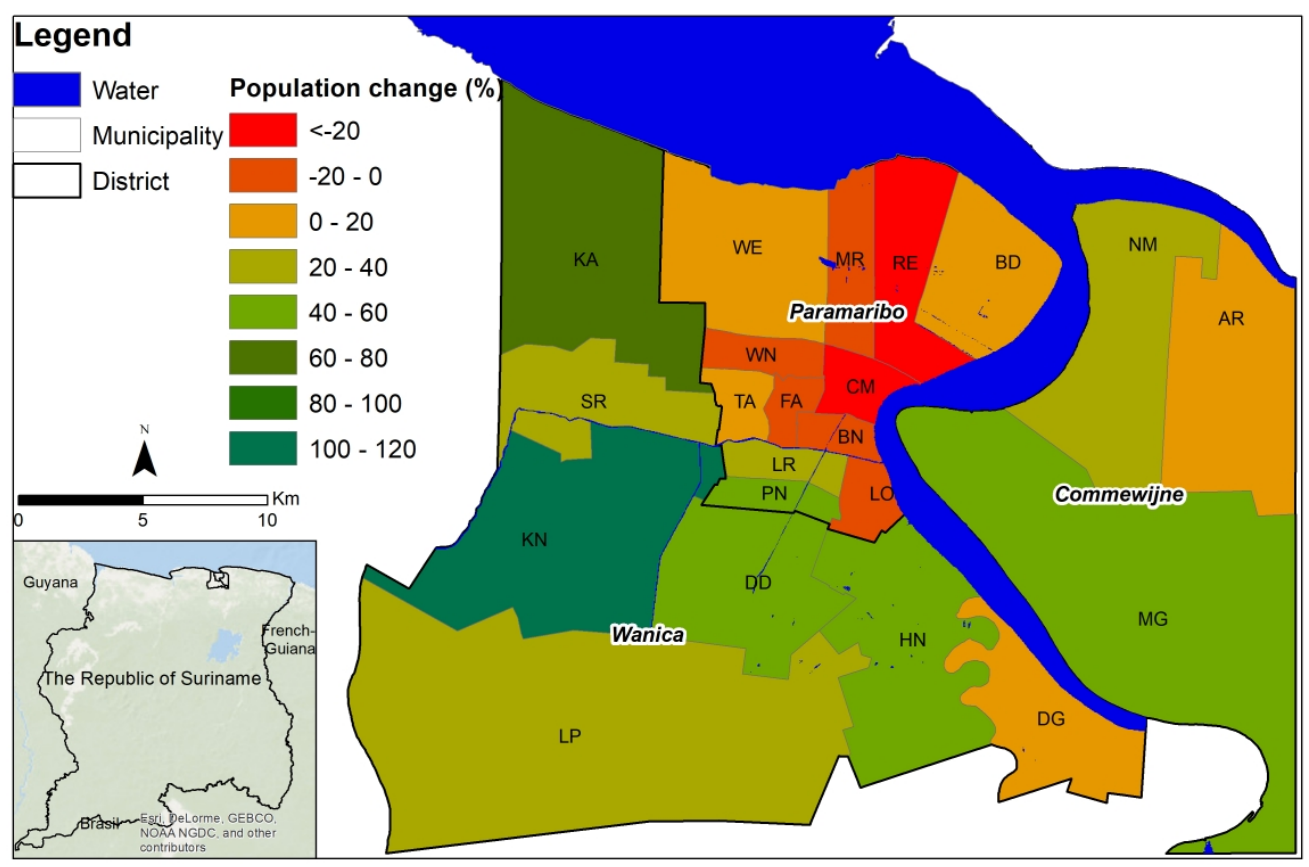




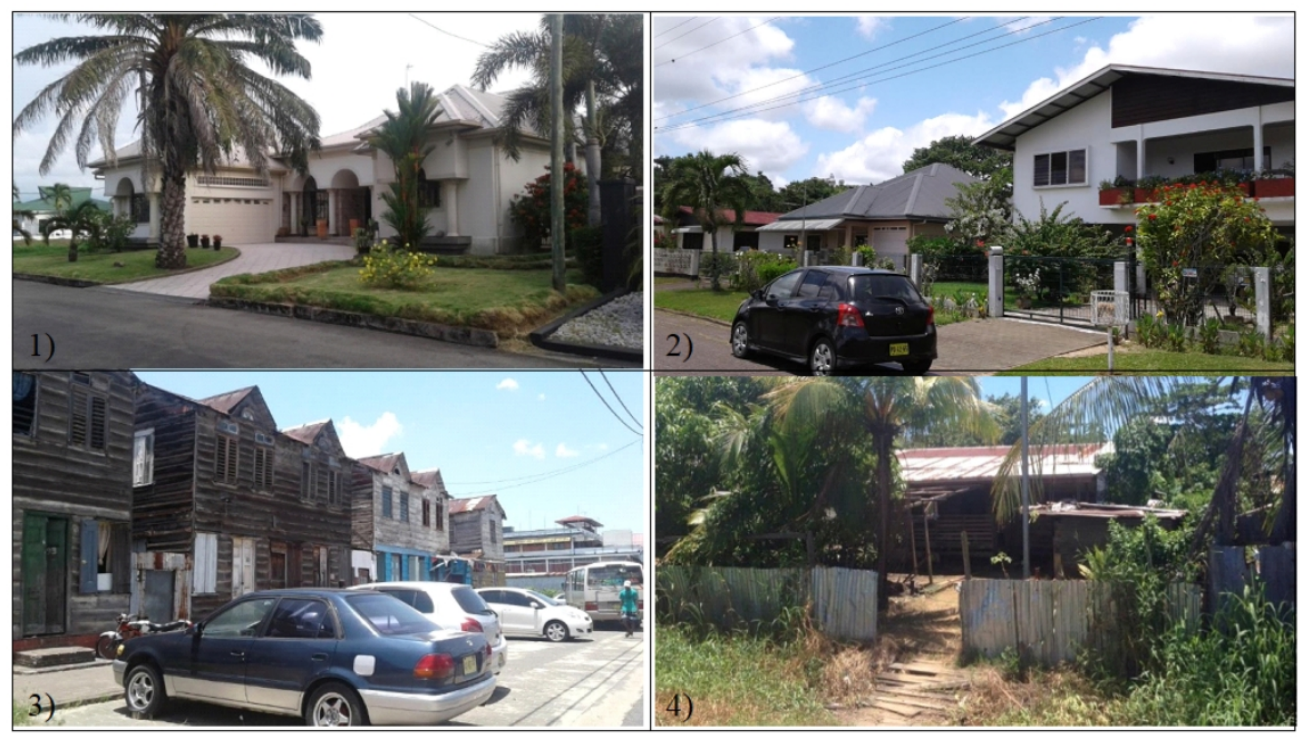

Figure 2: Examples of residences of the four socioeconomic groups; 1) Rich, 2) Middle, 3) Middle to low, and 4) Poor

$285 \times 161 \mathrm{~mm}(300 \times 300 \mathrm{DPI})$ 
a.

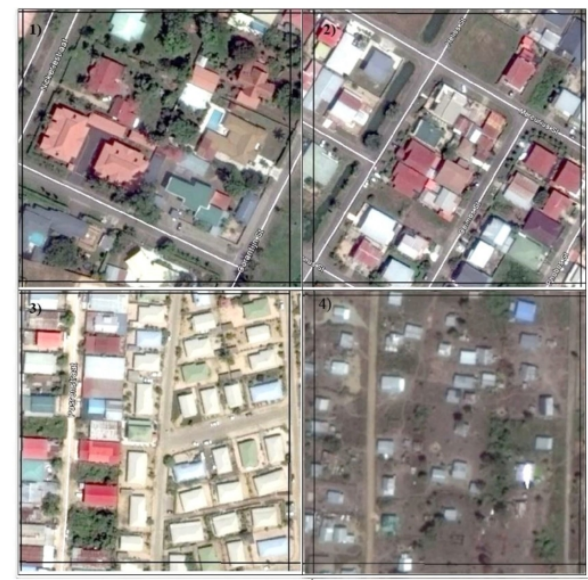

b.
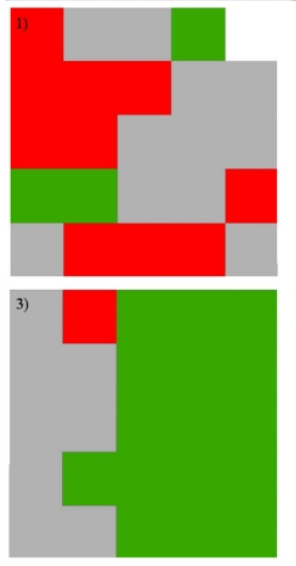
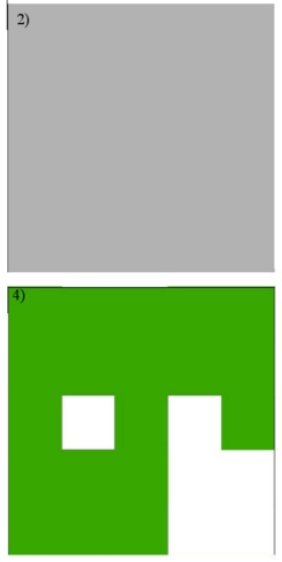

Categories:

1) Rich

2) Middle

3) Middle to low

4) Poor

\section{Legend}

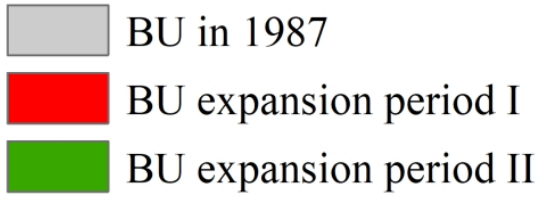

c.

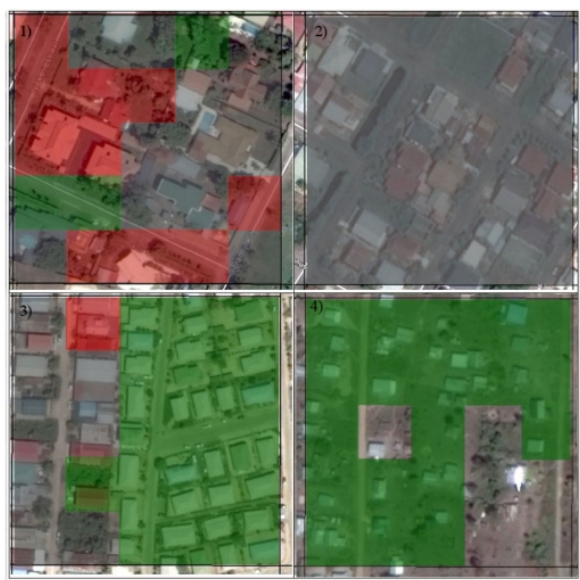

Figure 3: Residential differentiation method: a) Assignment of the four groups to the $150 \mathrm{~m} \times 150 \mathrm{~m}$ grid on the Google Earth (c) image; b) the built-up expansion layers of the different years, overlain with the classified grid layer; c) the final classification of the built-up area into the four groups. 


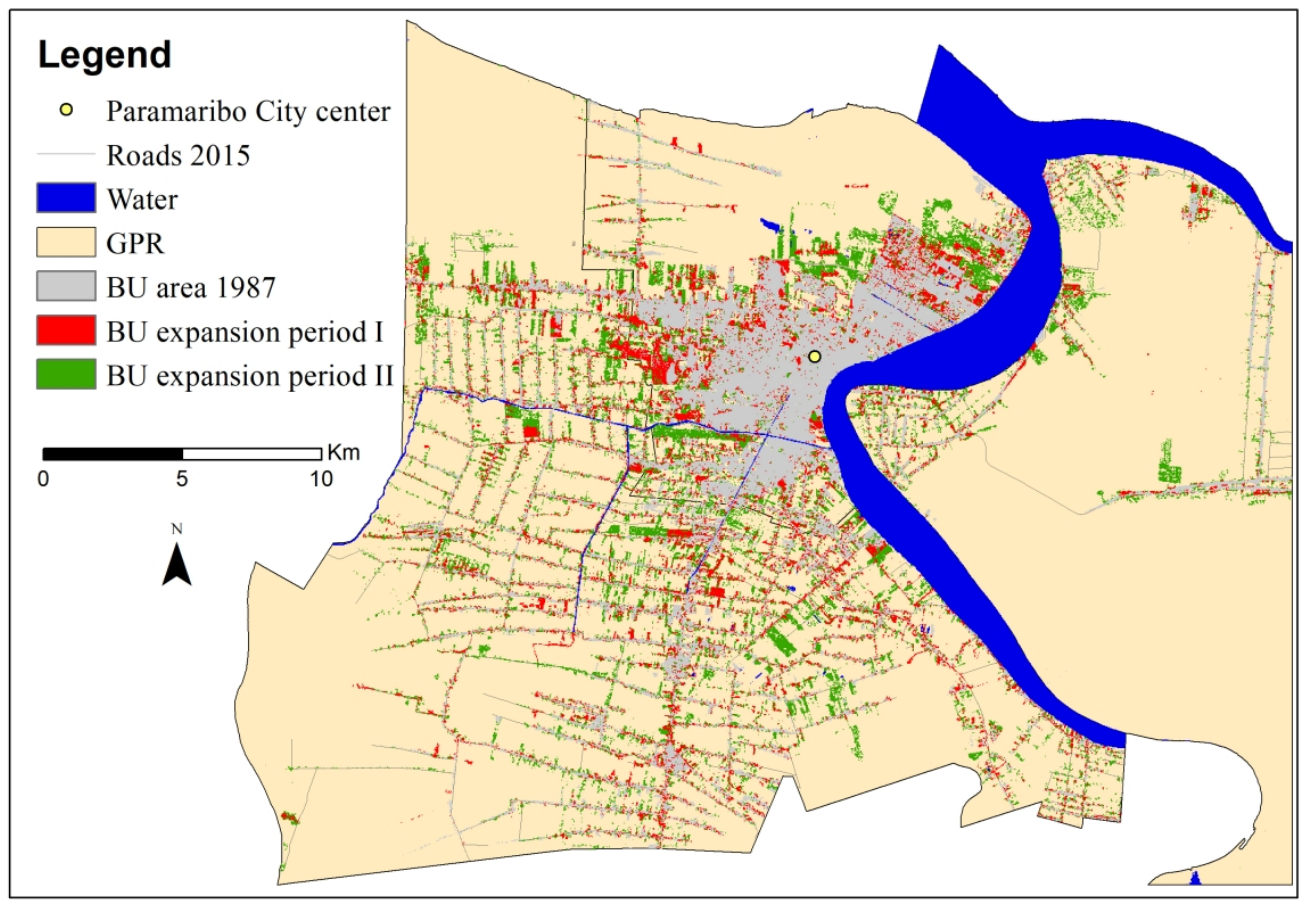

Figure 4: Built-up area expansion in the Greater Paramaribo Region, from 1987 until 2015 $241 \times 168 \mathrm{~mm}(300 \times 300 \mathrm{DPI})$ 


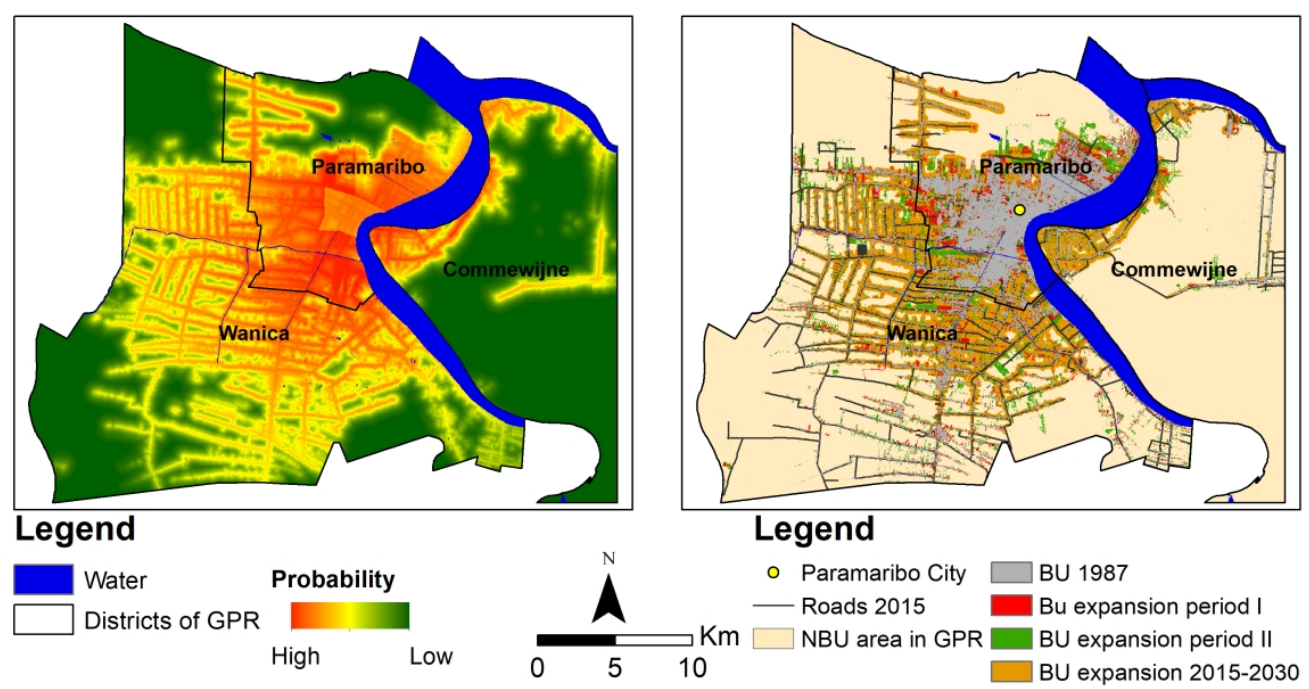

Figure 5: a) Probability maps for period II, based on the identified significant controlling factors of non-builtup to built-up change, and b) simulated built-up expansion for 2030, according to the probability map 


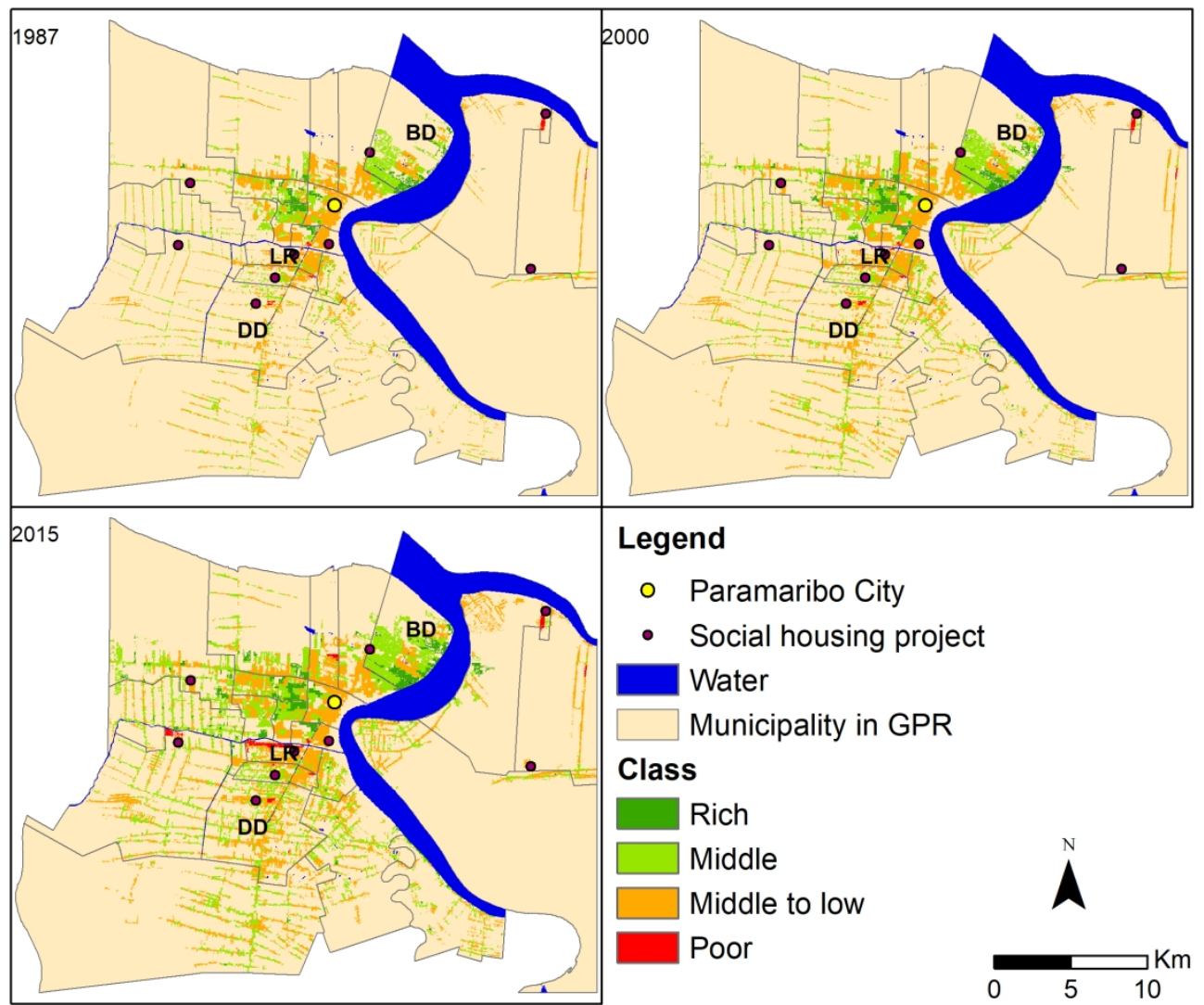

Figure 6: Residential differentiation of the different groups per municipality, throughout the years $197 \times 166 \mathrm{~mm}(300 \times 300$ DPI $)$ 


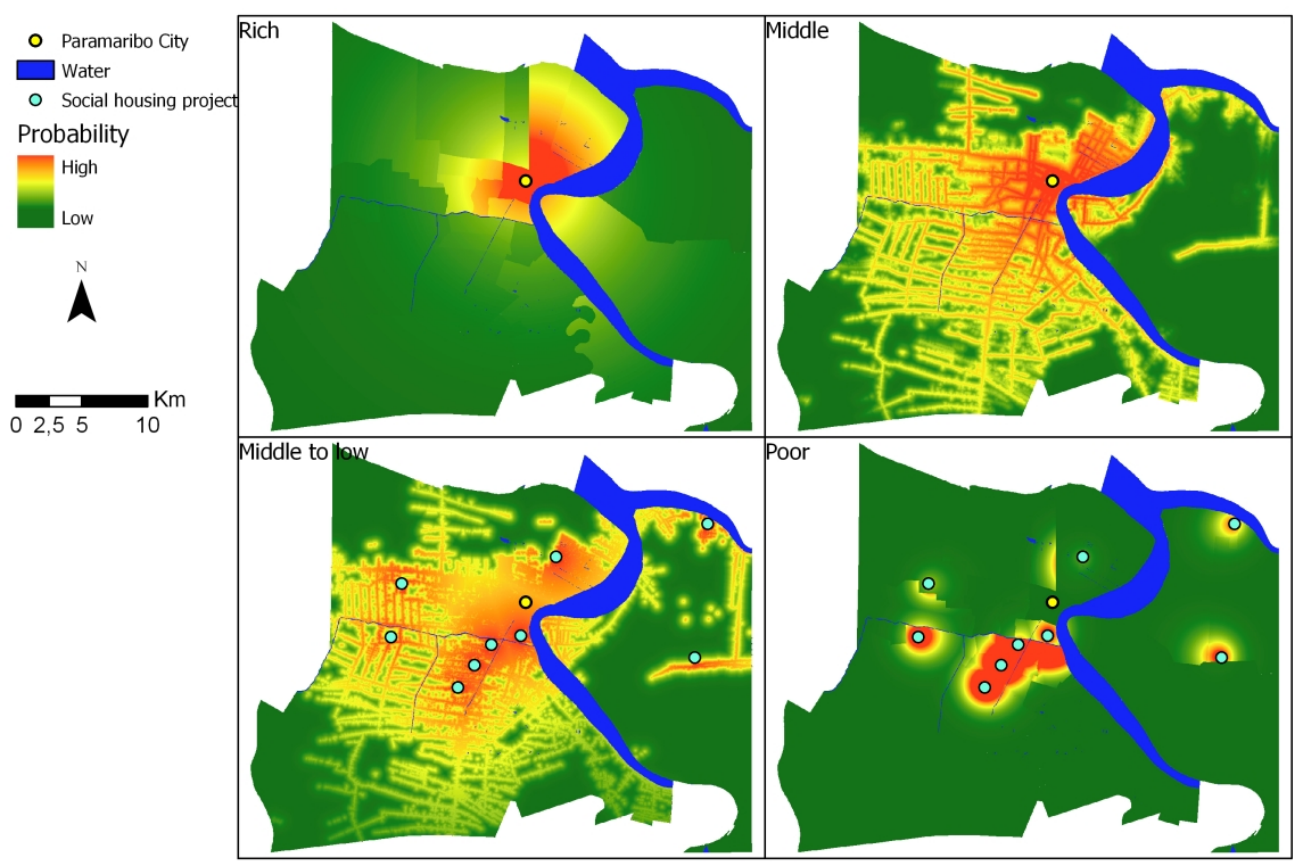

Figure 7: Probability maps for the different groups, based in their identified significant controlling factors of group expansion

$247 \times 163 \mathrm{~mm}(300 \times 300 \mathrm{DPI})$ 


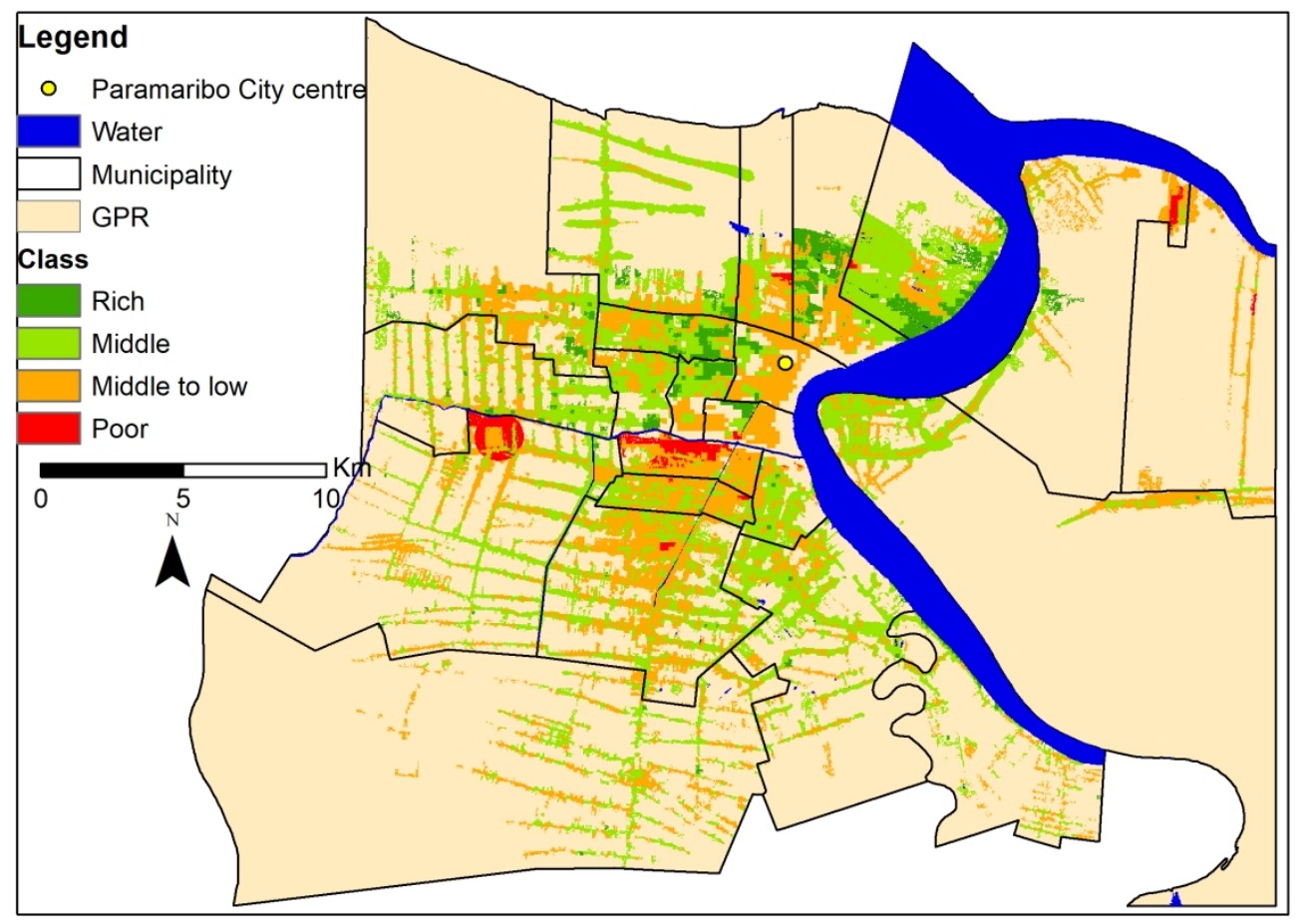

Figure 8: The residential built-up expansion per group simulated for 2030 $204 \times 146 \mathrm{~mm}(300 \times 300 \mathrm{DPI})$ 